Emerging Contaminants and Associated Treatment Technologies

Biljana Balabanova

Trajce Stafilov Editors

Contaminant

Levels and

Ecological Effects

Understanding and Predicting with

Chemometric Methods

Springer 


\section{Emerging Contaminants and Associated Treatment Technologies}

\section{Series Editors}

Muhammad Zaffar Hashmi, Department of Chemistry, COMSATS University Islamabad, Pakistan

Vladimir Strezov, Department of Environmental Sciences, Macquarie University Sydney, NSW, Australia 
Emerging Contaminants and Associated Treatment Technologies focuses on contaminant matrices (air, land, water, soil, sediment), the nature of pollutants (emerging, well-known, persistent, e-waste, nanomaterials, etc.), health effects (e.g., toxicology, occupational health, infectious diseases, cancer), treatment technologies (bioremediation, sustainable waste management, low cost technologies), and issues related to economic development and policy. The book series includes current, comprehensive texts on critical national and regional environmental issues of emerging contaminants useful to scientists in academia, industry, planners, policy makers and governments from diverse disciplines. The knowledge captured in this series will assist in understanding, maintaining and improving the biosphere in which we live. The scope of the series includes monographs, professional books and graduate textbooks, edited volumes and books devoted to supporting education on environmental pollution at the graduate and post-graduate levels.

More information about this series at http://www.springer.com/series/16185 
Biljana Balabanova - Trajče Stafilov

Editors

\section{Contaminant Levels and Ecological Effects}

Understanding and Predicting with Chemometric Methods

黛 Springer 


\author{
Editors \\ Biljana Balabanova \\ Faculty of Agriculture \\ Goce Delčev University \\ Štip, North Macedonia
}

\author{
Trajče Stafilov \\ Institute of Chemistry, Faculty of Natural \\ Sciences and Mathematics \\ Saints Cyril and Methodius University \\ Skopje, North Macedonia
}

ISSN 2524-6402

ISSN 2524-6410 (electronic)

Emerging Contaminants and Associated Treatment Technologies

ISBN 978-3-030-66134-2

ISBN 978-3-030-66135-9 (eBook)

https://doi.org/10.1007/978-3-030-66135-9

(C) The Editor(s) (if applicable) and The Author(s), under exclusive license to Springer Nature Switzerland AG 2021

This work is subject to copyright. All rights are solely and exclusively licensed by the Publisher, whether the whole or part of the material is concerned, specifically the rights of translation, reprinting, reuse of illustrations, recitation, broadcasting, reproduction on microfilms or in any other physical way, and transmission or information storage and retrieval, electronic adaptation, computer software, or by similar or dissimilar methodology now known or hereafter developed.

The use of general descriptive names, registered names, trademarks, service marks, etc. in this publication does not imply, even in the absence of a specific statement, that such names are exempt from the relevant protective laws and regulations and therefore free for general use.

The publisher, the authors, and the editors are safe to assume that the advice and information in this book are believed to be true and accurate at the date of publication. Neither the publisher nor the authors or the editors give a warranty, expressed or implied, with respect to the material contained herein or for any errors or omissions that may have been made. The publisher remains neutral with regard to jurisdictional claims in published maps and institutional affiliations.

This Springer imprint is published by the registered company Springer Nature Switzerland AG The registered company address is: Gewerbestrasse 11, 6330 Cham, Switzerland 


\section{Preface}

The biosphere is the medium that is naturally optimized for the growth and development of a huge number of biological organisms. Nature itself creates natural disasters that degrade the ecosystems and organisms that live in it. Humans, in spite of their existential question in nature, still continuously degrade nature and its living environment. This anthropogenic factor affects all segments of the environment, the lower parts of the atmosphere, the upper parts of the lithosphere, as well as the hydrosphere. Intensive technological development as well as the availability of natural raw materials for their utilization have significantly enabled the progress of these degradation processes in nature. On the other hand, the chemical and pharmaceutical industry, with their intensive development, have generated substances that are not only unnatural but also highly risky for the human population and the environment. Pollutants and potentially toxic substances are continuously introduced into all segments of the biosphere, shifting the natural balance of natural normal distributions. The environmental pollutants create abnormal media for living organisms. These days, we are increasingly faced with the fact of the ecological risk for the survival of many species. In recent decades, researchers have paid great attention to environmental risk, determining the pollution index and identifying polluted sites where it is necessary to prevent further degradation. Therefore, several critical aspects should be involved when we initiate and launch environmental research or monitoring. One of the aims of the modern environmental investigations is to obtain more objective data for the complex but silent environmental markers, which will be identified as typical pollutants in various parts of the environment. The modern analytical approaches involve sophisticated and sensitive instrumental technique, but the main question is how to create a corresponding data matrix and proper data analysis. Chemometrics is a routine chemical sub-discipline, which involves several mathematical methods for extracting more realistic and proper environmental information. The implementation of modern and novel chemometric methods becomes a critical point in the environmental studies these days. Therefore, this book summarizes the latest investigations of the concerning parts of the biosphere, affected with hazards substances. Moreover, selected case studies investigation with spacious applicability will create general framework of the opportunities, advantages, 
weaknesses, and anomalies of the mathematical approaches of the analysts. Furthermore, a properly defined chemometric model of each environmental investigation will provide long-term applicability potential.

This book consists of 13 chapters contributed by relevant experts in various fields correlated with environmental issues. All the chapters are logically selected and arranged to provide comprehensive state-of-the-art information about the practical aspects of environmental chemometric approaches. In this volume, the introductory chapter gives an overview of the critical environmental issues, such as degradation, ecological risks, and silent hazards. The next five chapters are on air pollution aspects: pollutants, hazardous emissions, monitoring, indication, as well as spatial indication of emission sources. This chapters give attention to air pollution, air deposition, and distribution models. Certain emphasis is given to the moss effectiveness for bioindication of the potential ecological risk. Another chapter is dedicated to the application of lichens as the main indicator in biological monitoring of air quality. Water pollutants and their determination issues are the main topics in the next two chapters, covering key issues in spatial distribution of various metals in different parts of the environment. These chapters deals with improving effective analytical methodologies of GC-MS and ICP-MS for tracking potential contaminants. This is followed by research into the effective removal of toxic hazard from aquatic systems. The next group of chapters is dedicated to the state of chemical characterization of the plant food and endemic plant species as characteristic media that involves the potential ecological risks. The presented are multidisciplinary approaches which enable detailed and precise elaboration of the set research subject.

All the chapters and their contents are supported by extensive citation of available literature; calculation and assumptions are based on realistic facts and figures of the present status of research and development in this field. This book will provide a wealth of information based on a realistic evaluation of contemporary development in environmental investigations with special emphasis on the latest research studies. Furthermore, this book also highlights the potential and perspective use of the multidisciplinary aspect for enchasing environmental pollution and potential ecological risks.

Most of the chapters cover advanced research as well as the use of more sophisticated methodologies. Therefore, we believe that the usefulness of this book will be primarily directed to experienced researchers. But of course we also encourage young researchers to use the book, because in many of the chapters, the methodologies used by the authors are explained very basically. We also believe that certain institutions and state regulatory bodies can use this book as an initiator for critical issues related to environmental degradation, environmental risks and their determination, and future prevention.

Štip, Republic of North Macedonia

Biljana Balabanova

Skopje, Republic of North Macedonia

Trajče Stafilov 


\section{List of Abbreviations}

$\begin{array}{ll}\text { AAS } & \text { Atomic absorption spectrometry } \\ \text { AED } & \text { Atomic emission detector } \\ \text { AES } & \text { Atomic emission spectrometry } \\ \text { AF } & \text { Attenuation factor } \\ \text { AFR } & \text { Revised attenuation factor } \\ \text { AFT } & \text { Log-transformed attenuation factor } \\ \text { ALA } & \text { Alpha linolenicacid } \\ \text { ANN } & \text { Artificial neural networks } \\ \text { ANOVA } & \text { Analysis of variance } \\ \text { APCI } & \text { Atmospheric pressure chemical ionization } \\ \text { ATP } & \text { Adenosine triphosphate } \\ \text { BAF } & \text { Biological accumulation factor } \\ \text { BTF } & \text { Biotransfer factor } \\ \text { CA } & \text { Cluster analysis } \\ \text { CART } & \text { Classification and regression trees } \\ \text { CDI } & \text { Chronic daily intake dose } \\ \text { CEC } & \text { Cation exchange capacity } \\ \text { CHCA } & \text { A-cyano-4-hydroxycinnamic acid } \\ \text { CR } & \text { Carcinogenic risk } \\ \text { CVAAS } & \text { Cold vapor atomic absorption spectrometry } \\ \text { DBCP } & \text { Dibromochloropropane } \\ \text { DCM } & \text { Dichloromethane } \\ \text { DHA } & \text { Docosahexaenoic } \\ \text { DMT } & \text { Digital terrain models } \\ \text { DRC } & \text { Dynamic reaction cell } \\ \text { DTPA } & \text { Diethylenetriamine pentaacetic acid } \\ \text { DW } & \text { Dry weight } \\ \text { EC } & \text { Elemental carbon } \\ \text { ECD } & \text { Electron capture } \\ \text { EDB } & \text { Ethylene dibromide } \\ \text { EDS } & \text { Energy dispersive X-ray spectrometry } \\ & \end{array}$




\begin{tabular}{|c|c|}
\hline EEA & European Environment Agency \\
\hline ELISA & Enzyme-linked immunosorbent assay \\
\hline EPA & Environmental Protection Agency \\
\hline EPA & Eicosapentaenoic \\
\hline ESI & Electrospray ionization \\
\hline ETAAS & Electrothermal atomic absorption spectrometry \\
\hline FID & Flame ionization detector \\
\hline FS & Fluorescence spectroscopy \\
\hline GC & Gas chromatography \\
\hline GHG & Greenhouse gas \\
\hline GLI & Global leachability index \\
\hline GUS & Groundwater ubiquity score \\
\hline GWCP & Groundwater contamination potential \\
\hline HI & Hornsby index \\
\hline HPLC & High-performance liquid chromatography \\
\hline ICP-AES & Inductively coupled plasma - atomic emission spectrometry \\
\hline ICP-MS & Inductively coupled plasma - mass spectrometry \\
\hline IR & Infrared spectroscopy \\
\hline IRMS & Isotope ratio spectrometry \\
\hline LA & Linoleic acid \\
\hline $\mathrm{LC}$ & Liquid chromatography \\
\hline LDA & Linear discriminant analysis \\
\hline LEACH & Leaching index \\
\hline LIX & Screening leachability index \\
\hline LLE & Liquid-liquid extraction \\
\hline LOD & Limit of detection \\
\hline LOQ & Limit of quantification \\
\hline LPI & Leaching potential index \\
\hline LSD & Least significant differences \\
\hline MAC & Maximum permissible concentrations \\
\hline MALDI & Matrix-assisted laser desorption/ionization \\
\hline MS & Mass spectrometry \\
\hline MSA & Multivariate statistical analysis \\
\hline NMR & Nuclear magnetic resonance \\
\hline ORS & Octopole reaction system \\
\hline $\mathrm{PC}$ & Principal components \\
\hline PCA & Principal component analysis \\
\hline PDA & Photodiode array \\
\hline PDO & Protected designation of origin \\
\hline PGI & Protected geographical indication \\
\hline PLP & Pesticide leaching potential index \\
\hline PTFE & Polytetrafluoroethylene \\
\hline PTH & Parathyroid hormone \\
\hline PTR-MS & Proton transfer reaction mass spectrometry \\
\hline RAF & Relative accumulation factors \\
\hline
\end{tabular}


REEs Rare earth elements

RLP Relative leaching potential index

SA Sinapic acid

SEM Scanning electron microscopy

TDS Total dissolved solids

TEP Thermoelectric power plant

TF Translocation factor

TGA/DTA Thermogravimetric and differential thermal analysis

TIN Triangular irregular network

TLC Thin layer chromatography

TOF Time-of-flight

TPP Triphenylphosphate

VI Volatility index 


\section{Contents}

1 General Aspects of Environmental Degradation vs. Technological Development Progression . . . . . . . . . . . . . . . . . . . 1 Biljana Balabanova

2 Spatial Series and Multivariate Analysis in Assessing the Essential (Cu and $\mathrm{Zn}$ ) and Toxic (As, Cd, Cr, Co, $\mathrm{Hg}$, $\mathrm{Ni}$ and $\mathrm{Pb}$ ) Metals Linked with Health Risk and Ecological Effects of Atmospheric Deposition by Using Bryophyte Moss as Bioindicator .

Shaniko Allajbeu, Lirim Bekteshi, Pranvera Lazo, Flora Qarri, and Trajče Stafilov

3 Moss Biomonitoring of Air Pollution Around the Coal Mine and Bitola Thermoelectric Power Plant, North Macedonia Trajče Stafilov, Robert Šajn, Mila Arapčeska, and Ivan Kungulovski

4 Lichens as the Main Indicator in Biological Monitoring of Air Quality Svetlana Ristić, Robert Šajn, and Slaviša Stamenković

5 Proposing Chemometric Tool for Efficacy Surface Dust Deposition Tracking in Moss Tissue Cross Bioindication Process of Metals in Environment

Biljana Balabanova, Maja Lazarova, Blažo Boev, Lucian Barbu-Tudoran, and Maria Suciu

6 Evidence for Atmospheric Depositions Using Attic Dust, Spatial Mapping and Multivariate Stats

Robert Šajn, Biljana Balabanova, Trajče Stafilov, and Claudiu Tănăselia 
7 Improving Quantitative Analysis of GC-MS for Tracking

Potential Contaminants in Groundwater . . . . . . . . . . . . . . . . 213

Biljana Kovacevik, Zoran Zdravkovski, Sasa Mitrev, and Natalija Markova Ruzdik

8 Groundwater Pollution Under the Intensive Agriculture Production

Biljana Kovacevik, Sasa Mitrev, Blažo Boev,

Natalija Markova Ruzdik, and Vesna Zajkova Panova

9 Removal of Chromium(VI) from Aqueous Solution by Clayey

Diatomite: Kinetic and Equilibrium Study

Hamdije Memedi, Katerina Atkovska, Stefan Kuvendziev,

Mrinmoy Garai, Mirko Marinkovski, Dejan Dimitrovski,

Blagoj Pavlovski, Arianit A. Reka, and Kiril Lisichkov

10 Chemometric Determination of Macro- and Microelements in Barley Genotypes with Different Origin Grown in the

Republic of North Macedonia . . . . . . . . . . . . . . . . 283

Natalija Markova Ruzdik, Verica Ilieva, Ljupcho Mihajlov,

Sonja Ivanovska, Sasa Mitrev, Darina Vulcheva, Dragomir Vulchev,

Biljana Kovacevik, and Mite Ilievski

11 Chemical Composition and Nutritional Properties of Functional

Food

Violeta Ivanova Petropulos and Biljana Balabanova

12 Characterization of Multi-element Profiles and Multi-isotope Ratio Records as a Tool for Determination of the Geographical Origin of

Various Plant Species

Liping Fan, Minxiu Yan, Meicong Wang, Yanqiu Liang,

Xiaoguang Kong, Chong Li, and Biljana Balabanova

13 Accumulation Abilities of Endemic Plant Species from the Vicinity of an As-Sb-Tl Abandoned Mine, Allchar, Kožuf Mountain

Katerina Bačeva Andonovska, Trajče Stafilov, and Vlado Matevski 


\title{
Chapter 6 \\ Evidence for Atmospheric Depositions Using Attic Dust, Spatial Mapping and Multivariate Stats
}

\author{
Robert Šajn, Biljana Balabanova, Trajče Stafilov, and Claudiu Tănăselia
}

\begin{abstract}
Atmospheric deposition poses significant ecological concerns. It is very important in air pollution researches to provide fast and efficient access to qualitative and quantitative characterization. Case study was introduced in order to implement the multidisciplinary approach in the investigations. When monitoring the distribution of certain substances in the air, it is necessary to choose very carefully the medium that will reflect not only the current but also the long-term atmospheric deposition. Attic dust was examined as historical archive of anthropogenic emissions, with the aim of elucidating the pathways of enrichments associated with exploitation of $\mathrm{Cu}, \mathrm{Pb}$ and $\mathrm{Zn}$ minerals in the Bregalnica river basin region. Attic dust samples were collected from 84 settlements. At each location for attic dust sampling, topsoil samples from the house yards were also collected. Mass spectrometry with inductively coupled plasma (ICP-MS) was applied as an analytical technique for multi-element determination. The universal kriging method with linear variogram interpolation was applied for the construction of spatial distribution maps. Data interpretation was considered in correlation with dominant geological units. Significantly enriched contents for $\mathrm{Cd}, \mathrm{Cu}, \mathrm{Pb}$ and $\mathrm{Zn}$ have been correlated with the lithogenic dominance of Rifeous shales. Both $\mathrm{Pb}-\mathrm{Zn}$ mine environs were identified as the most affected areas with lead and zinc enrichments, due to the
\end{abstract}

R. Šajn

Geological Survey of Slovenia, Ljubljana, Slovenia

B. Balabanova

Faculty of Agriculture, University "Goce Delčev",

Krste Misirkov bb, Štip, Republic of Macedonia

T. Stafilov $(\bowtie)$

Institute of Chemistry, Faculty of Science, Ss. Cyril and Methodius University,

Skopje, Republic of Macedonia

e-mail: trajcest@pmf.ukim.mk

C. Tănăselia

INCDO-INOE 2000 Research Institute for Analytical Instrumentation (ICIA),

Cluj-Napoca, Romania

(C) The Author(s), under exclusive license to Springer Nature

B. Balabanova, T. Stafilov (eds.), Contaminant Levels and Ecological Effects,

Emerging Contaminants and Associated Treatment Technologies,

https://doi.org/10.1007/978-3-030-66135-9_6 